\title{
Problematization Methodology and Convergent Healthcare Research: praxis proposal in research
}

\author{
Metodologia da Problematização e Pesquisa Convergente Assistencial: proposta de práxis em pesquisa
} Metodología de la Problematización e Investigación Convergente Asistencial: propuesta de praxis en investigación

\section{Laura Ferreira Cortes', Stela Maris de Mello Padoin', Neusi Aparecida Navas Berbel"}

' Universidade Federal de Santa Maria, Postgraduate Program in Nursing. Santa Maria, Rio Grande do Sul, Brazil. " Universidade Estadual de Londrina, Communication, Arts and Education Center, Department of Education. Londrina, Paraná, Brazil.

How to cite this article:

Cortes LF, Padoin SMM, Berbel NAN. Problematization Methodology and Convergent Healthcare Research: praxis proposal in research. Rev Bras Enferm [Internet]. 2018;71(2):440-5. DOI: http://dx.doi.org/10.1590/0034-7167-2016-0362

\section{Submission: 07-05-2016 Approval: 04-18-2017}

\section{ABSTRACT}

Objective: Presenting theoretical subsidies for the nursing care practice based on the possibility of convergence between research practice and educational practice. Method: The Convergent Healthcare Research was developed from February to August 2015, with an intersectoral working group formed by 32 participants, including health, social services and public safety professionals. Ten group meetings were organized, based on the Problematization Methodology with Maguerez's Arch. Results: The reflection-action movement resulted in the shared (re)building of the flowchart of care to women subjected to a situation of violence, as a device for communication between the services. Final considerations: The research practice based on the Problematization Methodology with Maguerez's Arch proved to be useful and viable in qualitative research, which has as purpose the transformation of the reality studied.

Descriptors: Health Care; Nursing; Research; Qualitative Research; Methodology.

\section{RESUMO}

Objetivo: Apresentar subsídios teóricos para a prática do cuidar em enfermagem pautada na possibilidade de convergência entre a prática investigativa e a prática educativa. Método: A Pesquisa Convergente Assistencial foi desenvolvida no período de fevereiro a agosto de 2015, com um Grupo de Trabalho intersetorial composto por 32 participantes, entre eles profissionais de saúde, assistência social e segurança pública. Foram desenvolvidos dez encontros grupais, pautados na Metodologia da Problematização com o Arco de Maguerez. Resultados: O movimento de reflexão-ação resultou na (re)construção compartilhada do fluxograma de atendimento às mulheres em situação de violência, como um dispositivo de comunicação entre os serviços. Considerações finais: Prática investigativa pautada na Metodologia da Problematização com o Arco de Maguerez mostrou-se profícua e viável em investigações qualitativas, cujo propósito seja a transformação da realidade em estudo.

Descritores: Atenção à Saúde; Enfermagem; Pesquisa; Pesquisa Qualitativa; Metodologia.

\section{RESUMEN}

Objetivo: presentar subsidios teóricos para la práctica de los cuidados en enfermería pautada en la posibilidad de convergencia entre la práctica investigativa y la práctica educativa. Método: la Investigación Convergente Asistencial se ha desarrollado desde febrero hasta agosto de 2015, con un Grupo de Trabajo intersectorial compuesto por 32 participantes, entre ellos profesionales de salud, asistencia social y seguridad pública. Se han desarrollado diez encuentros grupales, pautados en la Metodología de la Problematización con el Arco de Maguerez. Resultados: el movimiento de reflexión-acción resultó en la (re)construcción compartida del flujograma de atendimiento a las mujeres en situación de violencia, como un aparato de comunicación entre los servicios. Consideraciones finales: práctica investigativa pautada en la Metodología de la Problematización con el Arco de Maguerez se mostró provechosa y viable en investigaciones cualitativas, cuyo propósito sea la transformación de la realidad en estudio.

Descriptores: Atención a la Salud; Enfermería; Investigación; Investigación Cualitativa; Metodología. 


\section{INTRODUCTION}

Among the different ways of conducting research in health, the qualitative approach has been standing out in Nursing, since it aims to understand phenomena through people experiences, which are relevant to the field of situations of health and disease. It intends to interpret the meanings behind what the participants express about their actions and human relationships. In this sense, understanding the interactions between people and the system in which they are located is essential ${ }^{(1)}$.

In this context, the purpose of this article is to present theoretical subsidies for the nursing care practice based on the possibility of convergence between research practice and educational practice. Regarding the former, we present the Convergent Healthcare Research [Pesquisa Convergente Assistencial - PCA $]^{(2-4)}$. The latter is the teaching method called Problematization Methodology (PM) which uses Maguerez's Arch ${ }^{(5)}$.

PCA is a research methodological referential elaborated by nurses Dr. Mercedes Trentini and Dr. Lygia Paim. According to these authors, Kurt Lewin's research-action and the nursing process inspired the method's development in 1999. Thus, the PCA was designed for the Nursing field, although it can be applied in other fields in which practice directly involves people ${ }^{(4)}$. This research modality has been showing to be a socially accepted research alternative, with wide adherence in care practices, presenting evidence of changes in the Health Services Nursing practices ${ }^{(6)}$.

The PCA does not adapt to the demands of traditional paradigms in research, for example, the positivist one. It is an innovative experience oriented towards the humanist commitment of the researcher to studying and acting in health practice, based on the perspective of users and/or professionals involved in the investigated context. There is a movement of proximity and detachment between research and care, akin to a "dance" or interactive bridge, in which research information influences the care practice and the information obtained during practice fuels the research's questions. These two processes are autonomous, have their own identities and borders delimited according to the knowledge associated with each of them, as well as to the ethical aspects and scientific rigor ${ }^{(4)}$. It is within the synthesis of a process of articulation between the research approach and the nursing practice, which are simultaneously developed ${ }^{(6)}$.

The assumptions that support this method are: the context of care practice in health and nursing is a space where there are many phenomena to be unveiled, consisting of a fertile field for questions open to research; it consists of a space for care and action, but also for research and for the developing of theories, leading to innovations and to the link between theory and practice, in order to innovate and solve/minimize problems related to the latter; therefore, the research and care relationship vitalizes the live work $^{(4)}$.

The construct that names the method, convergence, must be highlighted. As a propeller, it has the property of connecting care actions to research actions at the same time and in the same physical space. This is considered the organizing core of the theoreticalphilosophical basis of the PCA, which is expressed through the juxtaposition between practice and scientific research, permeated by a continuous dialogical action. Thus, it produces commitment actions between the practice of researchers and the practice of health professionals ${ }^{(4)}$. When using the PCA, we must commit to the construction of new knowledge, new care methods and new technologies, allowing the innovation of care practice ${ }^{(3)}$.

In the PCA, the techniques to obtain information need to be compatible with its main characteristic: the participation of people involved in the research space, as well as in the care, research, coordination and convergence between theory and practice. In this sense, the PCA allows the integration of several options of techniques and methods, whether quantitative or qualitative. However, the difference is in the intention to produce scientific constructions in research activities and contribute to the care practice ${ }^{(2,4)}$.

Regarding the PM, it is being used in studies from the education, health and nursing fields and is based on Charles Maguerez's Arch. Created by this author in the 1960s and implemented in Brazil in 1968, the method was used to teach people, especially illiterate workers, to acquire knowledge to be applied in mines and factories ${ }^{(5)}$. In its second version, adapted by Juan Diaz Bordenave, the arch evolved into a teaching method supported by the principles of liberating/problematizing of education that opposes banking education. Therefore, the author proposed to solve the problem through a reflection with five stages, which are arranged starting from a base line placed over reality as a starting and finishing point. This author also found that the problematizing method is based on dialectical thinking(5,7).

Currently, the third adapted version of the arch, proposed by Neusi Berbel, is called Problematization Methodology (PM), and has been used in the teaching and research context. It is based on the logic of learning to learn and has, as a point of departure and arrival, a fragment of concrete reality, observed under various angles, which allows the student or researcher to extract and identify the issues existing within $i^{(5,7)}$.

The first step of the PM is the observation of reality and the defining of the issue. In this reality, one seeks to recognize the relationship between theory and practice in the context under study, so they may learn from reality and intervene to look for solutions to the real issues. After the issue to be studied has been defined, its determinants are reflected upon, enabling a greater understanding of its nature. This reflection will result in the definition of Key Points, affirmations or topics relating to aspects of the issue. The third step, Theorizing, is the constructing of answers to the issue. The data obtained are then analyzed and discussed, to assign meaning to them. In the fourth step, of the Solution Hypothesis, the alternatives for solution are considered. Finally, the last step, the Application to Reality, is what makes it possible to intervene and exercise situations associated with the solution of the issue. In this way, the PM provides the awareness of the complexity of social phenomena ${ }^{(5,7)}$. This method of teaching-learning is epistemically based on the liberating pedagogy of Paulo Freire ${ }^{(8)}$ and on the concepts of praxis by Marxist philosophers Karel Kosik and Adolfo Sánchez Vázquez ${ }^{(5,7)}$.

The liberating pedagogy of Paulo Freire converges with the PCA since it is grounded on a critical and liberating dialogue, based on the principle that critical reflection leads to action (practice), also known as praxis ${ }^{(8)}$. In this sense, the PM seeks, while based on dialectics and on the precepts by Paulo Freire, Karel Kosik and Adolfo Sánchez Vázquez, to stimulate the development 
of reasoning through the exploitation of data and information to enable the relationship between theory and practice. Thus, the PM causes changes in the involved participants, even during the learning process; this, in addition to the possibilities of application of the solution hypotheses elaborated, when there is intent to cause some transformation of reality. When used in research, there is intention to contribute to the solution or overcoming of an issue drawn from a fragment of reality. In this way, there is an association between researcher - with their respective vision, values and knowledge - , the social context/reality they are inserted in and the content being studied ${ }^{(5,7)}$.

It is at this point that the articulation of the PCA to the PM is propitious. Thus, this study is grounded on the account of the convergence between the two methods used in the research, which was the result of a doctoral thesis, developed with health and social care professionals about the strategies for the construction of a care network for women subjected to a situation of violence.

In the study in question, to produce the information, the technique of the Convergent Group (CG) was used, along with a field journal. The choice of these modalities is due to the fact they are techniques that have been used for performing PCA and, therefore, are recommended by the authors of the method. The convergent meetings consist in promoting discussions about a certain topic that is in line with the focus of the research, in a process of interaction and involvement between participants and researcher, thus enabling dialogicity ${ }^{(4)}$. In addition, they enable a process of group interaction based on exchanges and discoveries that arise from committed participation. In the research at hand, the group meetings were planned and developed with the PM as reference, subsidized by Paulo Freire's propositions that converge with PCA's referential. The PM was chosen to overcome the traditional teaching approach ${ }^{(5)}$, with the purpose of applying a method that provided a horizontal learning relationship between participants and researcher.

This method of teaching-learning is supported also by the concept of praxis that, in accordance with Karel Kosik ${ }^{(9)}$, is a way to see the world, things, processes, as we create them, as we reproduce them spiritually and intellectually in the relationship between human practice and reality in its most essential dimension, that is the creation of human social reality ${ }^{(5)}$.

In this sense, the PM applied as a methodological resource, as in the case of the reference research study at hand, guides the actions of the people involved implying in their consciences. In this way, it allows them to gradually distance themselves from a naive sort of consciousness, and advance toward critical consciousness, as it anticipates results and seeks their achieving as real products, thereby establishing a relationship between them, through investigation $^{(7)}$. Integrating this idea to the concept of praxis by Kosik, the PM is used as a means of migrating from everyday praxis, characteristic of a naive sort of consciousness, to a revolutionary praxis, a result of the critical conscience of reality ${ }^{(9)}$.

\section{METHOD}

Epistemological case studies on the use of Convergent Healthcare Research and the Problematizing Methodology with Charles Maguerez's Arch were assessed.

\section{The reference research}

The PCA was developed after the approval of the Human Research Ethics Committee at the Federal University of Santa Maria, where a favorable report was obtained. Ethical procedures were respected in all stages and moments of the research, in accordance with resolution No. 466/2012 of the National Health Council that subsidizes the ethical issues for the development of research involving human beings.

The period of production of the data was from February to August 2015, together with an intersectoral working group (WG) composed of health, social services and public safety professionals. This group, with the proposal of intervention in reality, had been (re)assessing issues concerning the care to people subjected to situations of violence in the city, as well as the prevention of suicide cases. Therefore, it was an opportune moment, considering the fact the study's proposal converged with the WG's needs, especially in what concerns the organization of services, so as to form a care network. The prior inserting of the researcher into the group determined the choice of setting and participants, conducted through a selection by convenience.

Thirty-two people participated in the study. Of these, 29 are professionals, in the categories: social worker, psychologist, nurse, nursing technician, pharmacist, doctor, police officer; and three are scholars, from the courses in social services or psychology. They attended the group meetings every two weeks.

Ten meetings were held, with an approximate 2-hour duration, which varied every meeting according to the mutual will of the participants. They were scheduled for the same days as the routine meetings of the TG, which happened before or after the intervention, in the WG, although at times the topics addressed coincided with the study's proposal.

Participation was dynamic, since there were new people at each meeting, requiring the researcher to reestablish the study's objectives, while inviting everyone to participate. This fact became a challenge in conducting some of the meetings, because as the group was already formed, other topics would come up at times, and the group would disperse from the focus of the meeting. At the same time, it was necessary to respect these moments, requiring the researcher to sit back and listen when the group discussed other topics associated with their daily practice.

The situation was understandable, since the theme of violence against women pervades the WG's discussions on situations of violence committed against other populations, such as older adults and children, and also on self-harm. Thus, sometimes, during the meetings, the group mobilized itself to also analyze the service network geared towards these populations. On the one hand, this seems to have been a productive movement of the WG, having happened from the reflection stimulated by the researcher and participants themselves, through the intervention that was being held. At that time, it was possible to identify convergence between healthcare research and practice. These discussions were well-received and the words of the participants, respected. The researcher was perceptive enough to notice these other demands of the 
group, making suggestions and propositions that maybe it was necessary to address these needs after the period of data production was over, or more specifically, at the time of the WG's meeting. On the other hand, one can infer that the very subject of violence against women, sometimes, can awaken in professionals hesitation or a certain need for distancing themselves. This fact demanded that at every meeting, the theme and focus of the study were readdressed.

Association between the Convergent Healthcare Research and the Problematization Methodology

The planning of each meeting was held based on the PM, starting with the problematization of the reality of professional practices. In order to make the participants feel welcomed, a simple snack was made available in each convergence group, organized so that participants would feel free to help themselves.

The convergent meetings were conducted considering the reality and experiences of the professionals. One thing to consider when using the PM is that it aims at the transformation of reality. With it, it is not intended to fully solve the problems of the world or of reality, but rather exercise interventions in some part of this reality ${ }^{(5,4)}$.

The meetings were based in Maguerez's Arch, in accordance with the application by Berbel ${ }^{(5)}$, which is developed in five stages: stage one - Observing of reality and defining of the studied issue; stage two - it begins with a reflection on the chosen issue, from which the key points that will be used in the third stage - theorizing -, emerge; stage four - elaboration of the solution hypotheses; stage five - application to reality, which refers to intervention, practice, in the exercising of the learned solutions associated with the problem. The latter allows fixating the generated solutions and encompasses the commitment of people in coming back to the same reality, generating some level of transformation ${ }^{(5,8)}$. In the reference study, the five stages of Maguerez's Arch proposed in the Problematization Methodology were covered in the 10 meetings.

\section{First Stage}

The first stage, held on the first and second meetings, is the observation of reality and definition of the issue extracted from practice: "the disarticulation of the care network geared towards women subjected to a situation of violence." It emerged from the observation of the topics discussed at the meetings of the
WG, before the PCA meetings and during the meetings of the convergence group. In the latter, the actions of the professionals were problematized, as well as the possibilities and difficulties for the construction of a care network geared towards women subjected to situations of violence in the city which served as the research's scenario.

\section{Second Stage}

The second stage was contemplated in the second meeting, after many reflections, and during it the key points to be studied by the group of professionals emerged: Ordinance No. 528, from April 1, 2013, which defines the rules for the licensing and operation of the Comprehensive Care Services for People Subjected to a Situation of Sexual Violence within the scope of the Brazilian Unified Health System (SUS); the Maria da Penha Law; the Network of care to women subjected to a situation of violence; and flowcharts.

\section{Third Stage}

The third stage, theorizing, occurred at meetings number $3,4,5,6$ and 7 through an educational intervention in which the topics identified in the previous step were discussed.

\section{Fourth Stage}

The fourth stage happened in sequence, when the following hypotheses of solution to the issue were defined: the collective (re)construction of a flowchart of care to women subjected to a situation of violence and the construction of an instrument of communication between services.

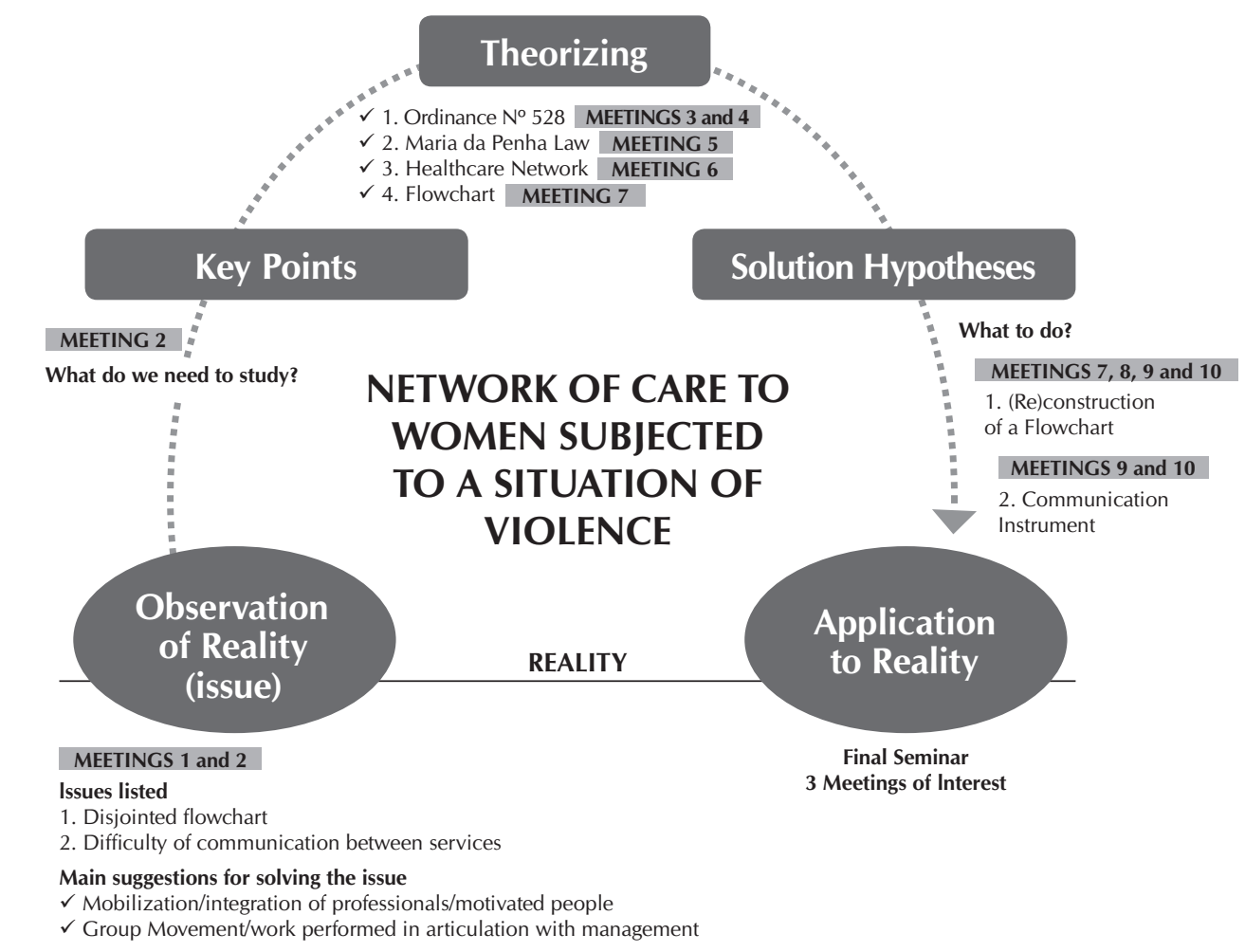

Figure 1 - Application of the Problematization Methodology with Maguerez's Arch in Convergent Healthcare Research 


\section{Fifth Stage}

The fifth stage, the application to reality, happened from the sixth to the tenth meeting, in which it was possible to collectively construct the two intervention products in order to contribute to the articulation of the services of care to women. It was also comprised of three meetings of interest (moments that emerged from the discussions, during the production of data, and that encompassed the need for articulation with the other services involved) and the seminar "Creating Networks for Fighting Off Violence Against Women," in which it was possible to socialize the products constructed in the PCA, based on the PM. Figure 1 shows the application of Maguerez's Arch to the study and illustrates the sequence of holding of meetings.

\section{RESULTS}

The provisions of the PCA allowed the participants to reflect on the practice and process of reflection/action, enabling the (re) construction of ideas and knowledge during the reflective process. This was possible to the extent the search for production of changes that add value to new practices is present in the PCA. It should be reaffirmed that, in the PCA, the basic strategy is the concomitant participation of the researcher, in healthcare practice and during the investigation, throughout the development of the research. This reciprocal strengthening of the PCA with practice, with the objective of generating transformations and new knowledge, brings together affinities in what concerns the common intention of innovating and finding new and concrete ways of conducting actions in health ${ }^{(2)}$.

Thus, the PM expresses the articulation between theory and practice, which is understood as a dialectical relationship. And, in this relationship, there is a permanent tension between the two, synthesized in the praxis, through which the two articulate with each other and knowledge is developed ${ }^{(6)}$, as one is fueled by the other. In the convergence between the two methods, this exercise was expressed by PCA's dance ${ }^{(4)}$, through which practice fuels the research data, instigating the researcher to seek new information and to deepen the existing knowledge while working along with the study participants.

Thus, the use of the PM with the PCA enabled the reflection instigated by each stage of the educational method, being stimulated by its particular characteristics, such $\mathrm{as}^{(8)}$ : being based on a fragment of reality, which in this case, is the articulation of the care to women subjected to a situation of violence; recognizing the relationship between theory and practice along the way; grasping the concrete reality to intervene in it; searching for solutions to problems (disarticulation of services of care to women subjected to a situation of violence); being aware of the complexity of social phenomena, in this case, violence against women, with the intention of transforming them. It should be highlighted that the products of the study contribute to the transformation of the reality studied through a critical and transformative reflection about the context of disarticulation, as well as through the (re) construction of the Flowchart of Service to Women Subjected to a Situation of Violence and the instrument to be used as a communication device between services.

The themes which arose during the research were validated in the groups and focused on the actions developed by the professionals in the different services involved; on the potentialities and difficulties encountered in the forming of a network of care to women subjected to a situation of violence; as well as on the appropriate content of an instrument for establishing a communicative articulation of the actions of care to women subjected to a situation of violence in the services, aiming at the construction of the network.

Finally, we highlight that the contribution of the study for Nursing and Health lies in the provision of subsidies for the implementation of the PCA with the PM and Maguerez's Arch, as a strategy for conducting qualitative studies that may converge with the demands of care aiming at the transformation of social reality. This study has as limitation the delimitation in the local scenario and the difficulty of keeping the focus during some of the meetings, because the participants were from different sectors, the meetings having being permeated by interaction.

\section{FINAL CONSIDERATIONS}

In the universe of qualitative research, Convergent Healthcare Research has shown to be a promising method to be used in Nursing and in Health, as it proposes the approximation between the context of professional practice and the production of knowledge in research. The PCA fosters research and, at the same time, the expansion and innovation of knowledge. This reinforces the fact that the practices used in this type of research are important tools for our nurses to work with or in the context of care, in which they all participate, learn and teach in a collective and simultaneous manner, seeking ways of transforming reality.

Their concomitant application proved to be useful and feasible to the extent the intersection of the methods happens through the praxis and in the transformation of the reality in which the researcher is inserted. The challenge for the use of the two methods is: at the same time the researcher exercises the praxis, they must conserve the scientific principles and methodological rigor. Another challenge is the requirement to turn away from the traditional paradigm of thought based on the natural and exact sciences, which indicates the need for insertion in the social context in which people live and relate to one another and for the seeking of the production of new knowledge to transform reality with.

\section{REFERENCES}

1. Minayo MCS. Análise qualitativa: teoria, passos e fidedignidade. Ciênc Saúde Colet[Internet]. 2012 [cited 2016 May 10];17(3):6216. Available from: http://www.scielo.br/pdf/csc/v17n3/v17n3a07.pdf

2. Bonetti A, Silva DGV, Trentini M. O método da Pesquisa Convergente Assistencial em um estudo com pessoas com doença 
arterial coronariana. Esc Anna Nery Rev Enferm[Internet]. 2013 [cited 2016 May 10];17(1):179-83. Available from: http://www. scielo.br/pdf/ean/v17n1/25.pdf

3. Rocha PK, Prado ML, Silva DMGV. Pesquisa Convergente assistencial: uso na elaboração de modelos de cuidado de enfermagem. Rev Bras Enferm [Internet]. 2012 [cited 2016 May 10];65(6):1019-25. Available from: http://www.scielo.br/pdf/reben/v65n6/ a19v65n6.pdf

4. Trentini M, Paim L, Silva DMGV. Pesquisa Convergente Assistencial: delineamento provocador de mudanças nas práticas de saúde. 3. ed. Porto Alegre: Moriá; 2014.

5. Berbel NAN. A Metodologia da Problematização com o Arco de Maguerez: uma reflexão teórico-epistemológica. Londrina: EDUEL; 2012.

6. Paim L, Trentini M, Madureira VSF, Stamm M. Pesquisa convergente-assistencial e sua aplicação em cenários da enfermagem. Cogitare Enferm [Internet]. 2008 [cited 2016 May 10];13(3):380-6. Available from: http://revistas.ufpr.br/cogitare/article/ view/12990/8775

7. Berbel NAN, Gamboa SAS. A metodologia da problematização com o Arco de Maguerez: uma perspectiva teórica e epistemológica. Filosofia e Educação (Online). [Internet]. 2012 [cited 2016 May 10];3(2):265-87. Available from: http://ojs.fe.unicamp.br/ged/rfe/ article/view/2363/2635

8. Freire P. Pedagogia do Oprimido. 50. ed. São Paulo: Paz e Terra; 2011.

9. Kosik K. A dialética do Concreto[Internet]. 7. ed. Rio de Janeiro: Paz e Terra. 2002 [cited 2016 May 21]. Available from: http:// www.outrafrequencia.org/2015/05/dialetica-do-concreto-karel-kosik.html 